Reserch Artide

\title{
ST UDENTS' APPRAISAL OF ONLINE INTERACTIONS WITH LECTURERS USING FACEBOOK
}

\section{Julius Che Tita; Stephen Mokondo Moki}

D epartment of Journalism and Mass Communication, University of Buea,Cameroon

\begin{abstract}
Facebook as a social network tool can be used to enhance students' learning. In addition to making available educational resources online that gives students' access to learning material of different formats anywhere and anytime, Couillard (2010), DeTeso (2011), Lam (2012), Pianta, Hamre and Allen (2012) and Gablinske (2014), maintain that it can also be used to enhance student-teacher relationship and hence improve on their grades. To investigate this assertion in the Cameroonian setting, we conducted a survey of 264 students of the University of Buea from the $4^{\text {th }}$ to the $16^{\text {th }}$ of June 2017 for their appraisal of their interactions with lecturers on Facebook. The results show that 73.4 per cent of the students have had no interaction with any of their lecturers on Facebook because they have never seen their lecturers profile or that they were rarely present online for those who have seen and were friends with them. The results also suggested a high probability for graduate students who interact with lecturers to have their grades improved on due to the interaction than undergraduates. A greater proportion $(43.6 \%)$ of the students reported that it was appropriate for lecturers to be on Facebook while only $29.7 \%$ stated that it was inappropriate. The results also indicate that students react better with their lecturers offline (13.6\%) compare to online $(4.0 \%)$.
\end{abstract}

Key words: Facebook, online interactions, lecturers, students

\begin{abstract}
Résumé
Facebook, l'un des outils des réseaux sociaux, peut être utilisé aux fins d'améliorer l'apprentissage des étudiants. O utre la facilité d'accès aux ressources didactiques en ligne, permettant aux étudiants d'acquérir du matériel éducatif sous différentes formes, quel que soit l'endroit ou l'heure, Couillard (2010), D eTeso (2011), Lam (2012), Pianta, Hamre and Allen (2012) and Gablinske (2014), pensent qu'il peut également servir à améliorer les relations entre étudiants et enseignants, améliorant ainsi leurs notes. A fin de mener une enquête sur cette affirmation dans un contexte purement camerounais, nous avons ciblé 264 étudiants de l'Université de Buea, de la période allant du 4 au 16 juin 2017, pour une évaluation de leurs relations avec des enseignants sur Facebook. Les résultats démontrent que 73,4\% des étudiants n'ont eu aucune interaction avec leurs enseignants sur Facebook parce qu'ils n'ont jamais pu trouver leurs profils ou encore parce que ceux-ci étaient rarement connecté, pour ceux qui les avaient trouvé et avec qu'ils avaient des liens d'amitié sur cette plateforme. Les résultats ont également suggéré une forte probabilité pour les étudiants du troisième cycle, qui communiquent avec les enseignants sur ce forum, d'avoir de meilleures notes que ceux du niveau licence, en raison de leur interaction avec leurs enseignants. Une grande majorité $(43,6 \%)$ des étudiants ont indiqué qu'il était acceptable pour des enseignants d'avoir des comptes Facebook alors que seulement 29,7\% ont pensé que cela était inacceptable. Les résultats démontrent aussi que les étudiants entretiennent de meilleures relations avec leurs enseignants de manière physique $(13,6 \%)$ par rapport à la toile $(4,0 \%)$.
\end{abstract}

Mots-clés: Facebook, interactions en ligne, enseignants, étudiants

(C) The Authors. This work is licensed under the Creative Commons Attribution 4.0 International Licence. 


\section{Introduction}

Students and teachers are bound to communicate in one way or the other once they come under the same academic environment. Pianta, Hamre and Allen (2012) hold that though students relationship with teachers are key to producing developmental changes in students, they argue this development can also be hindered depending to the extent that both parties engage. However, Gablinske (2014) maintains that there is a great deal of literature with empirical evidence supporting that it is essential for a strong studentteacher relationship in all schools for students to succeed in their academic life.

In addition to traditional mediums, there are many online forums or platforms where students can create interactive relationships with teachers. Interaction is a mode of communication that allows for a flow of information like sharing information on a school assignment. Lam (2012) states that only a reliable platform can facilitate the communication and interaction between students and teachers. One such forums or platforms student-teacher interaction can take place is the Facebook. It is an online platform used for social networking where people interact, exchange messages and share ideas and feelings (Yousif, 2013). Bart (2010) describes the Facebook as a social networking site with a structure that concretely suits a university environment. Facebook was initially designed by its CEO, Mark Zuckenburg to serve as a digital version of his Harvard physical class directories bearing a photograph of each student with some identifying facts, with walls to write on and party invitations to distribute (Cronin, 2009).

\section{Statement of the problem}

Interpersonal relationships play an important role in establishing a favourable learning environment between students and their teachers. Facebook has become one of the most used medium across the world since it provides possibilities for students to reach, communicate and to interact with their teachers and vice versa. Despite the advantages offered students-teachers on this platform, there are arguments that this can also serve as an inhibiting factor depending to the extent that both parties get engaged. Noting that there are a number of unresolved issues related to integrating Facebook into the educational milieu, this study hinges on providing a better understanding of what students find appropriate as far as student-teacher interaction on Facebook is concerned.Consequently, ths study examines whether the frequency of lecturers' presence online increases interactions with students and if this interaction improves academic performance. It also identifies the behaviours of lecturers which students find inappropriate. The findings will elucidate the benefits student-lecture interactions. Facebook for the development student's ability and performance in an academic milieu. This study will be limited to the student population across all faculties in the University of Buea, Cameroon. Students and teachers at this academic level are highly exposed to Facebook where they carry on lots of interactive activities with relatives, peers for different purposes including research (Che Tita $\&$ Cheo, 2014).

\section{Theoretical Framework}

This study is guided by the Uses and $\mathrm{G}$ ratification Theory. The uses and gratification theory which is credited to Katz and Blumler (1974) today was initially originated by Herta Herzog who was interested in studying how and why people listen to radio in the 1940s (Baran and Davis, 2010). This theory approach to media study focuses on the uses to which people put media and the gratifications they seek from those uses. Though proposed over four decades ago, the theory is still found relevant in communication research especially as technological development keeps 
providing media users with alternative media. Being driven by technology today, a good number human activity like education has gone online using social media platforms like Facebook. Students are connected with fellow classmates, teachers, relatives and loved one on this platform. It is therefore important to apply this theory in the study of students' appraisal of online interactions with lecturers using Facebook in order to appreciate what benefits they make from this interactions especially in relation to their academic grades.

\section{Literature Review}

The use of social networks has penetrated beyond many social and cultural boundaries to an extent that their presence cannot be avoided. The increasing popularity of their use is greatly enhancing many aspects of the social interaction, the educational sector included. Looking at open educational resources online, Harsasi (2015) holds that this gives students access to learning material of different formats anywhere and anytime and makes distance learning a reality.

While Al-Mashaqbeh (2016) holds that Facebook as one of the web tools of social networking can be used to enhance students' learning, Couillard (2015) notes that because of its structure and flexibility, Facebook has the potentials to become a learning platform for classroom related activities between students and teachers. Despite the development of diverse competing social networking sites, Mazman \& Usluel (2010) claimed Facebook has become the most popular since it was introduced in 2004. Looking at the positive aspects the use of technology offers to the learning environment, Dunn (2012) argues that active learning and deep interaction between students and their teachers requires an extended degree of technological engagement and hence, more emphasis must be placed on learning with technology.
However, despite the benefit web tools can provide students and educators, some scholar have reported that there are still lots of issues surrounding teachers and students integration using Facebook especially on issues not related to the classroom (Sang, 2014, McLoughlin \& Lee , 2010). Akiti (2012) disclosed two cases where teachers have been dismissed from their teaching position as fallouts resulting from their Facebook use with students. In one case, a parent gained access into her child's Facebook page and found a posting of her teacher on a beach with and alcoholic beverage. The parent reported this to the school principal and the teacher was dismissed the following day for "immoral misconduct" (Akiti, 2012, p. 119).

In other case reported by Akiti (2012), a female teacher posted a picture on a beach in a bathing suit, holding an alcoholic beverage. One of her Facebook friend who was her male student commented, "Looking sexy." This was followed by the female teacher composing and sending a message via Facebook with explicit, sexual references. A kiti (2012) goes further to explain that the conversations between the teacher and her student progressed to a physical level and ultimately resulted in a sexual relationship. The teacher was also dismissed after the student's parent uncovered the messages and reported the relationship to the principal and the police.

Aside the use of Facebook and other social networking sites for academic purposes, research has revealed that students also use this communication medium to feel connected to others, and for dating purposes, especially the development of romantic relationships (Fox, Warber \& Makstaller, 2013). Mansson and Myers (2011) finding suggest likability for women to express more affection over Facebook in relationships development than men will do. 


\section{Student-teacher interaction and academic performance}

Pianta et al (2012) describes the classrooms as a social place where students and teachers work together to create an environment in which all learning occurs. By interacting with their peers and teachers, the students can experience warm caring relationships they would enjoy (positive climate) or experience frequent yelling, humiliation, or irritation resulting to a negative learning climate.

Ilias and Nor (2012) studied student teacher relationship in the dimensions of control, submissive, resistance and corporation with the dimensions of motivational performance goals. From their findings, there was a positive significant relationship between dimensions of control with performance goals, no significant relationship between dimensions of submissive with performance goals, a positive significant relationship between the dimensions of the resistance with performance goals and no significant relationship between the dimensions of collaboration with performance goals.

Notwithstanding, DeTeso (2011) indicated that there will be a significant impact on a child's classroom behaviour over time depending on the relationship established during his interaction with his first teacher. He predicted competent behaviour from a child once that child establishes a "secure" relationship with his first teacher and on the other hand, predicted maladaptive behaviours like hostile aggression and withdrawn behaviour in case this relationship was not found secured. Scholars have observed the value and impact of interactions between student and teachers and argue that a positive relationship should be established between them as a means to motivate students to achieve their academic goals (Nugent, 2009, Pianta, 2012, Gablinske, 2014). In a study investigating how supportive relationship can improve the learning process between teachers and students, da Luz (2015) found out that students benefit and are motivated if a safe and trustful environment is created by their teachers.

In a study to understand students' perception of using Facebook as an interactive learning recourse at university, Leveritt (2012) holds that 78.0\% anticipated that a Facebook page would not only facilitate their learning, by increased interaction with students but also by increasing their interaction with instructors. Though this study does not state clearly if Facebook can enhance learning, it indicates that students welcomed the incorporation of Facebook into their academic lives due to perceived benefits in enhancing communication, interaction and flexibility in delivery the content of the course. Looking at group behaviour, scholars have reported possible negative outcome on students' academic achievement when assigned to teachers with a dissimilar demographic match. Egalitea, Kisidab, \& Wintersc (2015) did a race/ ethnicity test on academic performances among black and white students and found that students whose prior performances levels were lower turned to produce better results when assigned to teachers with a similar race/ ethnicity match.

Though Ehrenberg, Goldhaber \& Brewer (1995) found no facts in an earlier study to support the notion that student academic result is related to student-teacher gender pairing, Egalitea \& Kisidab (2016, p. 23) later found little convincing evidence of test score impacts connected with student/ teacher demographic pairings. Egalitea \& Kisidab (2016) further established that students averagely reported to have more favourable perceptions when their teacher is the same gender as them relative to when their teacher is a different gender. 
To further our understanding on group behaviour and attitude, Hewstone, Rubin \& Willis (2002) reviewed extensive literature to explain in-group and out-group bias using the social identity theory by Tajfel \& Turner 1979, optimal distinctiveness theory by Brewer 1991, subjective uncertainty reduction theory by Hogg \& Abrams 1993, and two others. Hewstone et al (2002) analysis explained intergroup as a systematic tendency for one to evaluate his/ her membership group (the in-group) or its members more favourably than a non-membership group (the out-group) or its members.

\section{Unexpected or Inappropriate Students/ teachers behaviour on social networks}

From wide experience, it is reported that though social networks provide a platform for students and teachers to enjoy fruitful interactions, they also encounter some unexpected behaviours from their counterparts on these platforms. Some of the unexpected behaviours on social media reported by D rouin, O 'Connor, Schmidt \& Miller (2015), are the posting of potentially damaging information online about others. According to Drouin et al. (2015), a teacher engaging in lewd behaviours on social media is also deemed to be inappropriate.

Sullivan (2010) cites a New York Times report where teachers were fired for flirting on Facebook with students. The teachers were accused of inappropriate "friending." It was reported that one teacher left a comment like, "This is Sexy," under a girls' pictures, the other made a lewder comment while others used Facebook to initiate real-life relationship with students (p. 1). Kimmons \& Veletsianos (in press) add that students have been punished for posting potentially unsuitable contents like nude photos and racial slurs on social media in the USA. The rise of inappropriate behaviour by educators on social media has questioned if restrictive policies are necessary to limit educators' social networking especially in sharing controversial material that engages them in inappropriate relationships with students over social networking. However, D ecker (2014) argues that such policies are not necessary as there are already existing laws to discipline employees that engage into inappropriate student relationships on or offline.

\section{Methodology}

Taiye (2005) holds that research methods are selected based on the goals and purpose of the researcher as well as how much fund is available to conduct the analysis. This study opted for a quantitative research with a survey as the main means of collecting data. A survey required the design of questionnaires that were administered face-to-face to respondents. The population was limited to students of the University of Buea. The reason for choosing students was that they understand and use Facebook on a daily basis. They could readily their experiences of their interaction with teachers on Facebook due to their level of education. The sampling technique was purposive random sampling. Purposive in the sense that only students who had Facebook accounts across different faculties in the university were allowed to participate in the study because with their exposure to the platform they could best discuss their experience with their teachers. Those without Facebook accounts were not allowed to fill the instrument because they would not have any experience to share regarding the subject matter.

\section{Instrumentation}

The instruments used for data collection was questionnaire. The questionnaire consisted of open and close ended questions and divided into four sections which included; Section one: Students Facebook Exposure, Section two: Students Experience Interacting with Teachers on Facebook (composed of questions to understand 
if student-teacher online relationship enhance their academic performance and questions to understand some behaviours of teachers on Facebook student's consider to be inappropriate) and demographic characteristics of the respondents. Q uestionnaires were administered to $10 \%$ randomly selected members of the population to pre-test the instrument.

\section{Data Collection}

Data for this study was basically collected from two sources which included primary and secondary sources. Data for the primary source was collected from respondents using questionnaires administered through face-to-face from the $4^{\text {th }}$ to the $16^{\text {th }}$ of June 2017. This was conducted by the researchers and four trainees from the Communication Research Center (CRC), Department of Journalism and Mass Communication. Sekaran \& Bougie (2013) state that personally administered questionnaires aids researchers to establish a rapport with the respondents that serve as motivation for them to respond to the questions. More so, it provides possibilities of clarifying respondents' doubts on the spot, it is less costly, ensures respondents' anonymity, and almost 100\% response rate is assured. The secondary data related to the topic was collected from the books, journals and other internet resources. A total of 300 questionnaires were sent to the field and some 270 were returned. After crosschecking, 6 of the questionnaires were discarded because they were not properly filled. Hence, the response rate for this study was $88.0 \%$

\section{Data Analysis}

The Statistical Package for Social Sciences (SPSS) version 22.0 was used to analyse data collected from respondents. Descriptive statistics such as cross tabulations were used to calculate for all dimensions and statements. For testing hypothesis, the chi-square test in SPSS was used to generate the probability values on relationships between students' views with respect to their experiences with teachers on Facebook. The main goal of using a chi-square test is to show whether there were significant differences in the views among the populations being tested in relation to their demographic characteristics. D ata that collected from the field will be coded and presented in crossed tables as well as the ChiSquare test results. The data was collapsed to a five point Lickert Scale to a three point scale. All the no responses were eliminated in order to avoid their effects on the Chi-Square test in each case.

\section{Results \\ Demographic description of respondents}

Participants for this study were aged between 17 to 51 years, with 48. percent representing those between 21-25 years, 32.2 percent for those bellow 20 years, $11.0 \%$ for those between $26-30$ years, $31-35$ years represented $3.4 \%, 0.8 \%$ for participants above 35 years and some 4.2 percent failed to indicate their ages. Majority $(60.6 \%)$ of the participants were females while $38.6 \%$ were males with just a 0.8 percent not indicating their ages. Also, most (80.3\%) of the participants were undergraduate students while just $19.9 \%$ of graduate students took part in the study. Of the 264 participants, $90.9 \%$ reported to be single, 7.6 percent married, $1.1 \%$ divorced and $0.4 \%$ reported to be widow(er).

\section{Findings}

\section{F requency of lecturer's presence on Facebook increases possibilities for students to interact with them}

All of the 264 students who responded during this study happened to use the Facebook, but $71.2 \%$ of them reported having no lecturer as a Facebook friend. Only $28.3 \%$ reported at least having a lecturer as a "friend" on this social media platform. Another $0.4 \%$ of them failed to respond to this question. Table 1 shows that those 
students who had teachers as Facebook friends interacted with them significantly more frequent than those who did not

Table 1: Frequency of lecturers present online and students interactivity

\begin{tabular}{|c|c|c|c|c|}
\hline \multirow{2}{*}{$\begin{array}{l}\text { Frequency of } \\
\text { students seeing } \\
\text { lecturers online }\end{array}$} & \multicolumn{3}{|c|}{ 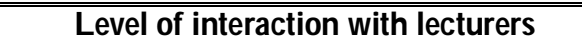 } & \multirow[t]{2}{*}{ Total } \\
\hline & $\begin{array}{c}\text { No } \\
\text { interaction }\end{array}$ & $\begin{array}{c}\text { Averagely } \\
\text { interact }\end{array}$ & $\begin{array}{c}\text { Always } \\
\text { interact }\end{array}$ & \\
\hline $\begin{array}{l}\text { Never/ rarely } \\
\text { seen }\end{array}$ & "164) 98.8\% & (2) $1.2 \%$ & (0) $0.0 \%$ & (166) 100.0\% \\
\hline Averagely & (20) $28.6 \%$ & (34) $48.6 \%$ & (16) $22.9 \%$ & (70) $100.0 \%$ \\
\hline Always & (1) $6.3 \%$ & (7) $43.8 \%$ & (8) $50.0 \%$ & (16) $100.0 \%$ \\
\hline Total & (185) $73.4 \%$ & (43) $17.1 \%$ & (24) $9.5 \%$ & (252) $100.0 \%$ \\
\hline
\end{tabular}

A Pearson's Chi-square comparing lecturers frequency

of presence online and students interactivity was computed and yielded the result, $\chi 2=171.842, \mathrm{df}=4, \mathrm{P}$-value $<.000$. This value indicates a significant difference at 0.000 level. Therefore, confirming the hypothesis that lecturer frequency online increases online interactions with students online.

\section{Graduateshudents reparted morefrequent interadions with letures on and offline than undegraduatestudents}

Table 2: Students level of intimacy with lecturers on and offline

\begin{tabular}{|c|c|c|c|c|c|c|}
\hline \multirow{2}{*}{$\begin{array}{l}\text { Level of } \\
\text { intimacy } \\
\text { with } \\
\text { lecturers } \\
\end{array}$} & \multicolumn{3}{|c|}{ Online intimacy } & \multicolumn{3}{|c|}{ Offline intimacy } \\
\hline & undengraduate & Graduate & Total & undergraduate & "Graduate & Total \\
\hline $\begin{array}{l}\text { Not } \\
\text { intimate }\end{array}$ & (162) $80.6 \%$ & (31)59.6\% & (193)76.3\% & & $\begin{array}{l}(20) \\
39.2 \%\end{array}$ & (139) $54.1 \%$ \\
\hline Neutral & (35) $17.4 \%$ & (15)28.8\% & (50) $19.8 \%$ & & $\begin{array}{l}(19) \\
37.3 \%\end{array}$ & (83) $32.3 \%$ \\
\hline Intimate & (4) $2.0 \%$ & (6) $11.5 \%$ & (10) $4.0 \%$ & (23) $11.2 \%$ & $\begin{array}{l}(12) \\
23.5 \% \\
\end{array}$ & (35) $13.6 \%$ \\
\hline Total & $\overline{(201) 100 \%}$ & $(52) 100 \%$ & $\overline{~(253) ~} 100 \%$ & (206) $100 \%$ & (51) $100 \%$ & (257) $100 \%$ \\
\hline \multicolumn{4}{|c|}{$\chi 2=14646, \mathrm{df}=2, \mathrm{P}$-value $<001$} & \multicolumn{3}{|c|}{$\chi 2=7.675, \mathrm{df}=2, \mathrm{P}$-value $<.022$} \\
\hline
\end{tabular}

G enerally, greater proportion of the students reported that they had no intimate relationships with lecturers both online $(76.3 \%)$ and offline $(54.1 \%)$, while only $4.0 \%$ and $13.6 \%$ reported that they had frequent interaction with lecturers on and offline respectively. Evidence from the data indicates that graduate student generally have more intimate relationships with lecturers both online (11.5\%) and offline (23.5\%) compared to undergraduate students online $(2.0 \%)$ and offline $(11.2 \%)$ respectively. However, a Chi-square tests, $\chi 2=14.646, \mathrm{df}=2$, P-value $<.001$ for level of education and intimacy with lecturers online and $\chi 2=7.675 \mathrm{df}=2$, P-value $<.022$ for level of education and intimacy with lecturers offline suggest that there is a significant difference .001 level for the former and no significant difference at .022 level for the later. Hence the hypothesis is confirmed for intimacy between students and teachers online and rejected for offline relationships.

Fackbodk interadion with letures improved gades for gaduate more than undegraduate students

Table 3: Student's interaction with lecturers and impact on their grades

\begin{tabular}{llllll}
\hline \hline \multirow{2}{*}{ Level } & \multicolumn{2}{c}{$\begin{array}{c}\text { To what extent has your interaction with } \\
\text { lecturers helped to improve your grades }\end{array}$} & Total \\
\cline { 2 - 4 } & $\begin{array}{c}\text { No } \\
\text { improvement }\end{array}$ & Neutral & Improved & \\
\hline Undergraduate & $(18) 9.9 \%$ & $(142) 78.5 \%$ & (21) $11.6 \%$ & (181) $100 \%$ \\
Graduate & $(1) 2.0 \%$ & (30) $60.0 \%$ & (19) $38.0 \%$ & (50) $100 \%$ \\
\hline \hline Total & (19) $8.2 \%$ & (172) $74.5 \%$ & (40) $17.3 \%$ & (231) $100 \%$ \\
\hline \hline
\end{tabular}

$\chi 2=20.564, \mathrm{df}=2$, P-value $<.000$ 
We found that more than half $(78.5 \%)$ of the undergraduate and graduate (60\%) participants reported to be neutral on the impact their interactions with lecturers has on their grades. Notwithstanding, we computed a Pearson's ChiSquare to test for level of education and the impact interaction with lecturers has on their grades and the test result was, $\chi 2=20.564, \mathrm{df}=2$, P-value $<.000$. The test indicates there is a high probability for graduate students who interact with lecturers to have their grades improved on than undergraduates, thus confirming the hypothesis.

\section{Femalestudents reparted moreletures' interadivebdhaviour they disiked on Facebook than male students}

Table 4: Student's appraisal of appropriate/ inappropriate behaviours of lecturers on Facebook vis-à-vis gender

\begin{tabular}{|c|c|c|c|c|c|}
\hline \multicolumn{2}{|l|}{ Activity } & Inappropriate & N Neutral & Appropriate & Total \\
\hline \multirow{3}{*}{$\begin{array}{l}\text { Teachers presence on } \\
\text { Facebook }\end{array}$} & Male & (31) $31.0 \%$ & (29) $29.0 \%$ & (40) $40.0 \%$ & (100) 100.0\% \\
\hline & Female & (46) $28.9 \%$ & (40) $25.2 \%$ & (73) $45.9 \%$ & (159) 100.0\% \\
\hline & Total & (77) $29.7 \%$ & (69) $26.6 \%$ & (113) 43.6\% & (259) 100.0\% \\
\hline \multirow{3}{*}{$\begin{array}{l}\text { Lecturers sending } \\
\text { students friend request }\end{array}$} & Male & (54) $52.9 \%$ & (28) $27.5 \%$ & (20) $19.6 \%$ & "(102) $100.0 \%$ \\
\hline & Female & (72) $45.3 \%$ & (39) $24.5 \%$ & (48) $30.2 \%$ & 100.0\% \\
\hline & Total & (126) 48.3\% & (67) $25.7 \%$ & (68) $26.1 \%$ & (261) 100.0\% \\
\hline \multirow{3}{*}{$\begin{array}{l}\text { Lecturers commenting } \\
\text { on students postings }\end{array}$} & "Male & (48) $48.5 \%$ & (32) $32.3 \%$ & 的 $19.2 \%$ & (99) $100.0 \%$ \\
\hline & Female & (70) $44.6 \%$ & (41) $26.1 \%$ & (46) $29.3 \%$ & (157) $100.0 \%$ \\
\hline & Total & (118) $46.1 \%$ & (73) $28.5 \%$ & (65) $25.4 \%$ & (256) $100.0 \%$ \\
\hline \multirow{3}{*}{$\begin{array}{l}\text { Lecture's chatting with } \\
\text { students on Facebook }\end{array}$} & Male & (37) $36.3 \%$ & (38) $37.3 \%$ & (27) $26.5 \%$ & "(102) 100.0\% \\
\hline & Female & (76) $48.1 \%$ & (33) $20.9 \%$ & (49) $31.0 \%$ & (159) 100.0\% \\
\hline & Total & (113) 43.5\% & (71) $27.3 \%$ & (76) $29.2 \%$ & (260) $100.0 \%$ \\
\hline \multirow{3}{*}{$\begin{array}{l}\text { Lecturers sending } \\
\text { students massages }\end{array}$} & Male & (33) $32.7 \%$ & (34) $33.7 \%$ & (34) $33.7 \%$ & "(109) $100.0 \%$ \\
\hline & Female & (61) $38.6 \%$ & (41) $25.9 \%$ & (56) $35.4 \%$ & (158) $100.0 \%$ \\
\hline & Total & (94) $36.3 \%$ & (75) $29.0 \%$ & (90) $34.7 \%$ & (259) $100.0 \%$ \\
\hline \multirow{3}{*}{$\begin{array}{l}\text { Lecturers joining } \\
\text { students Facebook } \\
\text { group }\end{array}$} & "Male & (50) 50.5\% & (21) $21.2 \%$ & (28) $28.3 \%$ & (99) $100.0 \%$ \\
\hline & Female & (73) $46.5 \%$ & (31) $19.7 \%$ & (53) 33.8\% & (157) 100.0\% \\
\hline & Total & 48.0\% & (52) $20.3 \%$ & (81) $31.6 \%$ & (256) 100.0\% \\
\hline \multirow{3}{*}{$\begin{array}{l}\text { Lecturers poking } \\
\text { students on Facebook }\end{array}$} & Male & (64) $65.3 \%$ & (22) $22.4 \%$ & (12) $12.2 \%$ & (98) 100.0\% \\
\hline & Female & (102) 65.0\% & (34) $21.7 \%$ & (21) $13.4 \%$ & (157) 100.0\% \\
\hline & Total & (166) 65.1\% & (56) $22.0 \%$ & (33) $12.9 \%$ & (255) $100.0 \%$ \\
\hline
\end{tabular}

The table above represents students' appraisal of lecturers' behaviours on Facebook. A cross tabulation using gender was done to measure how students will respond to some Facebook activities lecturers are likely to be involve with students. A Pearson Chi-Square test to test the hypothesis that female students will report more lecturers' interactive behaviour they dislike on Facebook than male students was also conducted. We found that the students had mixed reactions in appraising the different activities lecturers can get involved with then on Facebook.

A greater proportion (43.6\%) of the students reported that it was appropriate for lecturers to be on Facebook while only $29.7 \%$ reported that it was inappropriate and some $26.6 \%$ of them remained neutral. However, more female students (45.9\%) supported lecturers' presence on Facebook while more male students $(31.0 \%)$ reported their dislikes. The Chi-Square statistics, $\chi 2=0.920, \mathrm{df}=2, \mathrm{P}$-value $<.631$ indicates a very small probability that there is difference in terms of students likes and dislikes of lecturers presence on Facebook based on their gender.

Almost half of the respondents (48.3\%) indicated that it was inappropriate for lecturers to send friend request to students, $26.1 \%$ said it was appropriate and $25.7 \%$ stayed neutral. More than half (52.9\%) of male students reported that it was inappropriate for lectures to be involved in sending friend request to students compared to only $30.2 \%$ of the female students. No significant 
difference was produced at $\chi 2=3.632, \mathrm{df}=2$, $\mathrm{P}$-value $<.163$, hence rejecting the hypothesis that female students will dislike lecturers sending students friend request than male students.

More students (46.1\%) reported lecturers commenting on students postings on Facebook to be inappropriate compared to $25.4 \%$ who stated that it was appropriate. Closed to half (48.5\%) of male students stated that this act was inappropriate compared to $44.6 \%$ for female students. The Chi-Square statistics, $\chi 2=3.464$, $\mathrm{df}=2$, P-value $<.177$, produce no significant difference to support gender difference among the students on lecturers commenting on students' postings.

Some $43.5 \%$ of the participants stated that it was inappropriate for lecturers to chat with students' on Facebook while on the other hand, $29.2 \%$ said it was appropriate. More females (48.1\%) than males (36.3\%) reported that it was inappropriate for lecturers to chart with students. The test, $\chi 2$ $=8.514, \mathrm{df}=2, \mathrm{P}$-value<.014 indicates no significant difference to confirm that female dislike lecturers chatting with students than males. The study found little difference among respondents appraisal of lecturers sending student messages on Facebook. The 36.3\% of those who reported this to be inappropriate was closed to those who reported it to be appropriate (34.7\%). Also, the Chi-Square test results, $\chi 2=1.920$, df $=2$, P-value $<.383$ shows a very little probability for female students to dislike lecturers involvement in this activity.

A greater percentage of the participants (48.0\%) also indicated it was inappropriate for lecturers to join students' Facebook group while 31.6\% said it was appropriate. Slightly above half $(50.5 \%)$ male students noted that it was inappropriate compared to $46.5 \%$ female students who mentioned that it was appropriate. The Chi-
Square test, $\chi 2=0.843, \mathrm{df}=2$, P-value $<.656$ produced no significant difference on students likes and dislikes of lecturers joining students' Facebook group based on gender. Majority $(65.1 \%)$ of the participants stated that it was inappropriate for lectures to pock students on Facebook while only $12.9 \%$ said it was appropriate. In terms of gender, $65.3 \%$ and $65.0 \%$ male and female students respectively reported that it was inappropriate for lecturers to pock students. A comparative analysis predicting difference in gender attitude using Chi-Square test gave the result, $\chi 2=0.078, \mathrm{df}=2$, P-value $<.962$ yielded no significant difference that female students will dislike lecturers pocking students than male students.

\section{Discussion and Conclusions}

This study was initially designed to investigate if student-lecturer Facebook relationships can enhance the students' academic performance and to find out if there were some behaviours of lecturers on Facebook students consider to be inappropriate. Generally, the findings of this study suggest students in the University of Buea have very little interaction with lecturers on Facebook. We found that 73.4 percent of the students never had any interaction with their lecturers. Amongst these students, some have never seen the Facebook profile of their lecturers while some who are even friends with lecturers reported that the lecturers were scarcely present online. G raduate students seem to benefitmore from their Facebook interaction with lecturers than undergraduate students. Some $38.0 \%$ of graduate students confirmed that they had their grades improved on because of their interactions with lecturers compared just $2.0 \%$ who reported no improvement in their grades. This was not the case with undergraduate students. Majority of them $78.5 \%$ remained indecisive. 
The study also suggest that students disliked lecturers sending students friend request, commenting on students postings, chatting with students, sending students massages, joining students Facebook group and pocking students on Facebook. A greater proportion of them seem to have no problem with lecturers' presence on Facebook. A greater proportion of male students are reported to dislike lecturers' involvement in more Facebook activities (presence, sending students friend request, commenting on students posting, joining students Facebook groups and pocking students) than female students. On the other hand, female students reported their dislikes of lecturers' chatting with students and sending messages to them on Facebook than male students.

Facebook groups should be encourage for all the courses where the lecturer of the course and the students should be encouraged to have academic exchange just as in a normal classroom. Students can pose questions and lecturers and other students react to make contributions. For future study, another study should be conducted on lecturers' appraisal of online interactions with students to get their own views. Further research should also be encouraged to understand reasons why students consider some lecturers' activities on Facebook to be inappropriate.

\section{References}

Al-Rahmi, W. M., O thman, M. S. And Yusuf, L. M. (2015) The Role of Social Media for Collaborative Learning to Improve Academic Performance of Students and Researchers in Malaysian Higher Education. Intemational Review of Rearch in Open and Distributed Leaming 16(4): 177-204.

Asterhan, C., Rosenberg, H., Schwarz, B., Solomon, L. (2013) Secondary School Teacher-Student Communication in Facebook: Potentials and
Pitfalls. Proceedings of the Chais conference on instructional technologies research 2013: Learning in the technological era. Y. Eshet-Alkalai, A. Caspi, S. Eden, N. Geri, Y. Kalman, Y. Yair (Eds.), Raanana: The O pen University of Israel.

Baran, S., J. and Davis, D., K. (2010) Mass Communication Theory Foundations, Ferment, and Future, ${ }^{6 \text { th }}$ ed. Boston, Wadsworth, Cengage Learning.

Che Tita, J. \& Cheo, V. N. (2014). Internet Use by University of Buea Students: O ccasionally using Cybefcafes to do Assignmnets, African Journal of Special Education. 2(1) 116-137.

Callison, A. (2015) Student-Teacher Boundary Issues. DeConcini Law Firm Paper presented at the ASBA Law Conference 2015. Retrieved from www.azsba.org/ wp-content/ .../ 09/ ThursdayBR13-Student-Teacher-Boundaries.pdf..

da Luz, Fredson Soares dos Reis. (2015). The Relationship between Teachers and Students in the Classroom: Communicative Language Teaching Approach and Cooperative Learning Strategy to Improve Learning in BSU. Master's Theses and Projects. Item 22. Available at http:/ $\angle$ vc.bridgew.edu/ theses/ 22 accessed on 0 ctober 28th 2016.

D ecker, J. R. (2014) Facebook Phobia! The Misguided Proliferation of Restrictive Social Networking Policies for School Employees. Nothmestem Jaumal of Law\& Soial Pdig, Vol. 9, Iss (2): pp. 162-205. Accessed on November 7, 2016 from http:/ / scholarlycommons.law.northwestern.edu/ njlsp/ vol9/ iss2/ 1.

DeTeso, J. A. (2011) Student-Teacher relationships as predictors of reading comprehension gains in 2nd grade. Submitted in partial fulfilment of the requirements for the 
degree of Doctor of Philosophy under the Executive Committee of the G raduate School of Arts and Sciences. Columbia University.

Drouin, M., O 'Connor K. W., Schmidt, G. B., Miller, D. A. (2015) Facebook fired: Legal perspectives and young adults' opinions on the use of social media in hiring and firing decisions. Computers in Human Behavior Jaumal accessed on November 7, 2016 from www.elsevier.com/ locate/ comphumbeh.

Egalitea, A. \& Kisidab, B. (2016) The Effects of Teacher Match on Academic Perceptions and Attitudes. Paper presented at the 2016 meeting of the Association for Education Finance and Policy.

Egalitea, A. J., Kisidab, B., \& Wintersc, M. A. (2015) Representation in the classroom: The effect of own-race teachers on student achievement. Econamics of Education Review 45, 44-52.

Ehrenberg, R. G., Goldhaber, D., \& Brewer, D. J. (1995). D o teachers' race, gender, and ethnicity matter? Evidence from the National Educational Longitudinal Study of 1988. Industrial and Labor Reations Review 48(3), 547-561.

Fox, J., Warber, K. M., \& Makstaller, D. (2013).The role of Facebook in romantic relationship development: An exploration of Knapp's relational stage model. Jaumal of Social \& Personal Relationships, 30: 771-794. doi:10.1177/ 0265407512468370.

Grossecka, G., Branb, R., \& Tiruc, L. (2011) D ear teacher, what should I write on my wall? A case study on academic uses of Facebook. Procedia Social and Behavioral Sciences Vol. 15: pp. 14251430.

Gurcan, H. I. (2015) Contribution of Social Media to the Students' Academic Development.
Intemational Journal of Information and Education Techndogy, 5 (12): 965-968.

Hewstone, M., Rubin, M. \& Willis, H. (2002) Intergroup Bias. Anmu Rev. Psydh. 53:575-604. Accessed on November 12, 2017 from arjournals.annualreviews.org.

Jackson, E.A. (2016). Integration of Learning Technology in Sierra Leone's Higher Education System: Implications and Challenges. The Online Jaumal of NewHorizons inEducation 6 (3): 99-112. Kimmons, R., \& Veletsianos, G. (in press).

Teacher Professionalization in the Age of Social Networking Sites: Identifying Major Tensions and Dilemmas. Learning, Media, and Technology.

Langmia, K. and Glass, A. (2014) Coping with Smart Phone 'D istractions' in a College Classroom. TeadhingJoumalismand Mass Communication 4 (1): 13-23.

Mansson, D. H., \& Myers, S. A. (2011). An initial examination of college students' expressions of affection through Facebook. Southern Communication Jaumal, 76, 155-168. doi: 10.1080/ 10417940903317710.

Mboga, J., Mboga, M., Nyaanga, S. (2016) Distractions in Learning Institutions: An Explorative Case Analysis of Mobile Device Usage in Kenyan Academia. Intemational Joumal of Eduration and Rearch 4(3): 115-126.

Sekaran, U., \& Bougie, R. (2013). Research Methods for Business: A skill Building Approach (6 $6^{\text {th }}$ Ed.).Chichester: John Wiley \& Sons, Ltd.

Sullivan, B. (2010) Teachers, Students and Facebook, A Toxic Mix. Posted: Friday, O ctober 222010 at 07:00 am. Retrieved on November 7, 2-16 from http:/ / redtape.msnbc.com/ 2010/ 10/ the-head lines-conjure-up-every-parents- 
nightmare-teachersfired-for-flirting-on-facebookwith-students-the-new-york-post-r.html.

Voorn, R.J.J \& Kommers, P.A.M. (2013) 'Social media and higher education: introversion and collaborative learning from the student's perspective', Int. J. Sodial Media and Interadive Leaming Enironmets 1 (1): 59-73.

Yousif, A. A. (2013) University Students' Use of Social Networks Sites and their Relation with Some Variables. WEI International Academic Conference Proceedings, January 14-16, 2013, Antalya, Turkey.

Akiti, L. (2012). Facebook off Limits? Protecting Teachers' Private Speech on Social Networking Sites. Valparaiso University Law Review, Art 4, Vol.47, No.1, pp. 119-167. Available at: http:// scholar.valpo.edu/ vulr/ vol47/ iss1/ 4.

Al-Mashaqbeh, I., F. (2015). Social media in practice: The challenges of using Facebook in higher education. Malaysian Journal of Distance Education 17(2): 37-50. doi: 10.21315/ mjde2015.17.2.3

Bart, Mary. (2011). Professors Use Twitter to Increase Student Engagement and Grades. Faculty Focus. Retrieved February, 15, 2011, from http:// www.facultyfocus.com/ articles/ teachingandlearning/ professors-use-twitter-to-increasestudent-engagement-and-grades

Couillard, C., 2010. Facebook: The Pros and Cons of Use in Education. Master of Science Degree in Information and Communication Technologies. Menomonie: University of Wisconsin-Stout.

Cronin, Michael J., "The purpose of Facebook: The value of Facebook friends in increasing selfperceived popularity" (2009). Honors Program Theses, 69. htt:/ / scholarworks.uni.edu/ hpt/ 69.
Davis, F. D., Bagozzi, R. P., \& Warshaw, P. R. (1989). User acceptance of computer technology: A comparison of two theoretical models. Management Science, 35(8), 982-1003.

Dunn, L. (2012) Why It's Time To Start BOYD In Your School on Edudemic. http:/ / edudemic.com/ 2012/ 12/ why-its-time-to-startbyod-in-your-school/ Accessed on January 12, 2017.

Gablinske, P.B. (2014). A Case study of student and teacher relationships and the effects on student learning, Open Access Dissertations, Paper 266. Retrieved on February 10, 2017 from http:// digitalcommons.uri.edu/ oa_diss/ 266.

Gordon, T., W. ed. (2003) Marshall McLuhan's 1964 Understanding Media; the extensions of man-Critical Edition, Berkeley, Gingko Press Inc.

Harsasi, M. (2015) The Use of O pen Educational Resources in Online Learning: A Study of Students' Perception. Turkish O nline Journal of Distance Education-TOJDE July 2015 ISSN 1302-6488 Volume, 16 No. 3, Article 6, p. 74-87.

Irwin, C., Ball, L., Desbrow, B. \& Leveritt, M. (2012). Students'perceptions of using Facebookas an interactive learning resource at university. Australasian Journal of Educational Technology, 28(7), pp. 1221-1232. http:/ / www.ascilite.org.au/ ajet/ ajet28/ irwin.htm.

Lam, L. (2012). An innovative research on the usage of Facebook in the higher education context of Hong Kong. Electronic Journal of e-Learning, 10(4), 378-386.

Lenhart, A., Purcell, K., Smith, A., \& Zickuhr, K. (2010). Social media and young adults. Washington, D C: Pew Internet and A merican Life Project cited in page 1, Junco, R. (2015) Student 
class standing, Facebook use, and academic performance. Journal of Applied Developmental Psychology 36, pp. 18- 29.

Mazman, S. G. \& Usluel, Y. K. (2010). Modeling Educational Usage of Facebook. Computers \& Education, Vol. 55(2), PP. 444-453. http:// dx.doi.org/ 10.1016/ j.compedu.2010.02.008.

McLoughlin, C., \& Lee, M. J. W. (2010). Personalised and self-regulated learning in the Web 2.0 era: International exemplars of innovative pedagogy using social software. Australasian Journal of Educational Technology, 26(1), 28-43.

Michae l A. Stefanone, M., A., Lackaff, D., and Rosen, D. (2011) Contingencies of Self-Worth and Social-Networking-Site Behavior. Cyberpsychology, Behavior, and Social Networking, Vol. 14, No. 1-2, 2011, pp. 41-49. D O I: $10.1089 /$ cyber.2010.0049.

Mukherjee, A., Hoare, D., and Hoare, J. (2002) Selection of research methodology for $\mathrm{PhD}$ researchers working with an organization. In: Greenwood, D (Ed.), 18th Annual ARCOM Conference, 2-4 September 2002, University of Northumbria. Association of Researchers in Construction Management, Vol. 2, pp. 667-76.
Pianta, R. C., Hamre, B. K., \& Allen, J. P. (2012). Teacher-student relationships and engagement: Conceptualizing, measuring, and improving the capacity of classroom interactions. In S. L. Christenson (Ed.), Handbook of student engagement (pp. 365-386). New York, NY: Guildford.

Ryan, T. \& Xenos, S. (2011). Who uses Facebook? An investigation into the relationship between the Big Five, shyness, narcissism, loneliness, and Facebook usage. Computers in Human Behavior27 (2011) 1658-1664.

Sang, W., S. (2014) The criteria of students' and teachers' communication privacy management in Facebook and their effect on teacher -student relationship Thesis submitted to the Center for media pedagogy, Faculty of education, University of Lapland for an award of Master of Arts in Media Education.

Received: 12/ 09/ 2017

Accepted: 01/ 12/ 2017 